\title{
Status of Greenhouse Farming in the Coastal Humid Climatic Region of Kenya
}

\author{
Sanzua L. J", Saha H. M, Mwafaida J \\ Pwani University, P.O. Box 195-80108, Kilifi, Kenya
}

Copyright $\bigcirc 2018$ by authors, all rights reserved. Authors agree that this article remains permanently open access under the terms of the Creative Commons Attribution License 4.0 International License

\begin{abstract}
The performance of greenhouses in the humid coastal region of Kenya has consistently been poor despite the huge market potential that exist for fresh farm produce. A study was conducted to establish the extent of greenhouse technology uptake and distribution pattern in the region with a view to establish production status and challenges faced by greenhouse farmers. A survey was conducted in Kwale, Kilifi and Mombasa counties between July and August 2015. Data was collected through semi-structured questionnaires, random interviews and observation using purposive sampling method. The study established that $69 \%$ and $100 \%$ of the greenhouses surveyed in Kwale and Mombasa Counties respectively were owned by institutions and farmer groups. In Kilifi County however, more individuals own greenhouses with over $60 \%$ of the greenhouses owned by two farmers who produce for export. There was marked variation on the spatial distribution of greenhouses in the three counties with the relative area under greenhouse in the region averaging $0.0003 \%$. Most of the installed greenhouses in the region had been abandoned. The rate of failure was highest in Kwale County where only $30 \%$ of those surveyed were operational. In Kilifi and Mombasa Counties however, $70 \%$ of the existing greenhouses were operational. Greenhouse farming in the coastal humid region faced several challenges including low productivity averaging $10 \%$ of the potential; political interference, lack of technical know-how, lack of adequate water sources and in certain instances low water quality usage for production. These challenges largely contributed to the poor adoption of the greenhouse technology in the region under study. With increased technical support, greenhouses can be a more viable economic booster especially in the urban and non-traditional agricultural areas.
\end{abstract}

Keywords Greenhouse Technology, Relative Humidity, Ventilation, Agricultural Productivity

\section{Introduction}

Greenhouse farming is a technology that is widely used in Europe to promote efforts to achieve food security. It has spread to other continents such as the Americas, Asia and India including Africa though in a much smaller scale. In Kenya, greenhouses have been used commercially to produce cut-flowers for export. The scenario is slowly changing with small scale farmers adopting it to grow high value food crops such as tomatoes, strawberries and melons among other crops. Despite this positive trend, greenhouse farming is not vibrant in the hot humid tropical climate region of Kenya. Excess temperature, solar radiation, and high vapor pressure deficit are major greenhouse concerns. These extreme conditions increase plant stress and decrease crop productivity and fruit quality [1]. Humidity affects growth, pollination and flower setting [2]. Other Studies have shown that, for greenhouse crops, high levels of humidity can lead to yield losses (Jolliet et al. [3]. Humidity affects growth of greenhouse crops mainly through its impact on leaf size and light interception [4]. According to [5], relative humidity in the greenhouse can be regulated by fog system [6]. Under cool temperatures and low daylight, humidity levels rise within the greenhouse and fungal infections can occur. It is preferred that the greenhouse is kept well ventilated and dry during such conditions. Lack of access to technical knowhow in greenhouse management has contributed to a large extent in the reduced rate of uptake of greenhouse technology by small scale farmers [7]. An evaluation study carried out in western Kenya revealed that poor management of greenhouse environment resulted to tomato crops performing at $20 \%$ of the optimal. Continued lack of access to technical services on the technology led to $60 \%$ of farmers in Kisumu County to abandon the technology [7]. This present study sought to establish the status of greenhouse farming in the hot coastal humid region of Kenya with specific interest to establish the level of technology adoption, performance of installed greenhouses and challenges faced by greenhouse farmers in the region. 


\section{Methodology}

Greenhouse technology is perceived to be a relatively new technology in the hot humid coastal region of Kenya. To establish areas to be included in the survey, consultations were made with the Ministry of Agriculture and Livestock Development, State Department of Agriculture and the commercial greenhouse distributors in three counties namely; Kilifi, Mombasa and Kwale. Purposive sampling was therefore used to identify the administrative locations to be surveyed based on the extent of greenhouse technology adoption in those counties. Selected locations included Golini and Msambweni in Kwale County; Kongowea, Likoni and Bamburi locations in Mombasa county; Kikambala, Mnarani, Kilifi township, Matsangoni and Malindi.

\section{Project Area}

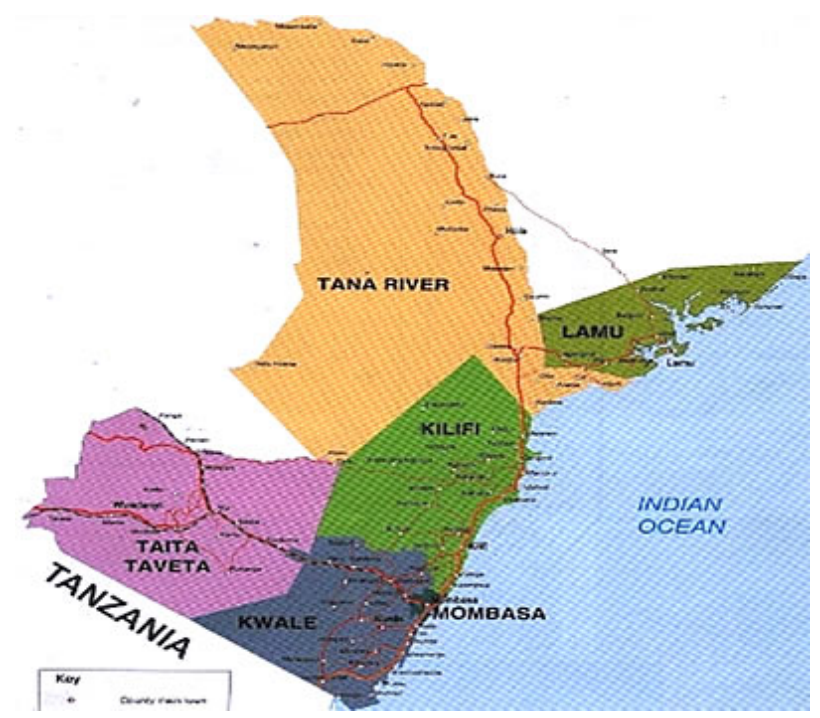

The survey was conducted between July and August 2015. Data was collected through semi-structured questionnaires, random interviews and observation using purposive sampling method.

\section{Data Analysis}

Data was analysed by simple excel software and presented in graphs, tables and charts.

\section{Results}

\section{Status of Greenhouse Farming in the Coastal Humid Region of Kenya}

It was established that Greenhouse farming in the project area was still at introduction stage with most of the greenhouses found in Institutions and groups within the communities. In Kwale County eleven out of the sixteen greenhouses surveyed were owned by groups and institutions, while in Mombasa $100 \%$ of the greenhouses were owned by schools, churches and Children's welfare centers. There was a slight shift in trend observed in Kilifi County where more individuals owned greenhouses than institutions. However over $60 \%$ of the individual greenhouses in the County were owned by two farmers who produce for export. The technology had been in the region for the past four years. Over $50 \%$ of the greenhouses were donations by charity foundations, politicians and oil companies.

There were several greenhouse designs observed in the field. Eighty three percent of the greenhouses were from commercial companies with Amiran Kenya distributing 80\% of the commercial greenhouses in the Coastal Humid region. There were modifications found with some farmers who had lined the ceilings of the commercial greenhouses with shade nets to reduce trapped radiation.

\section{Pictures of Greenhouse Types Found in the Study Counties}
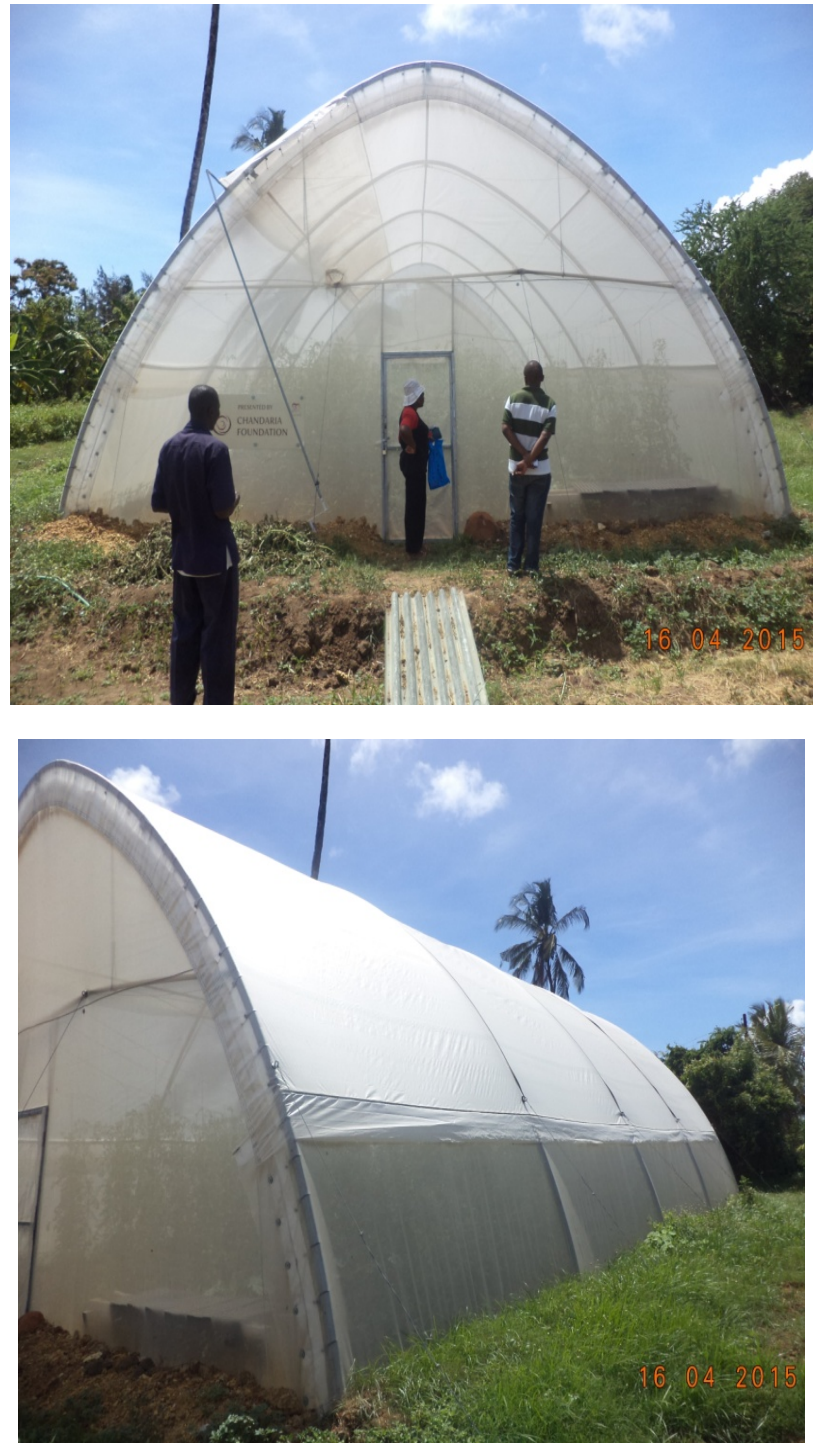

Figure 1. Amiran Design-3 at Wema Centre 

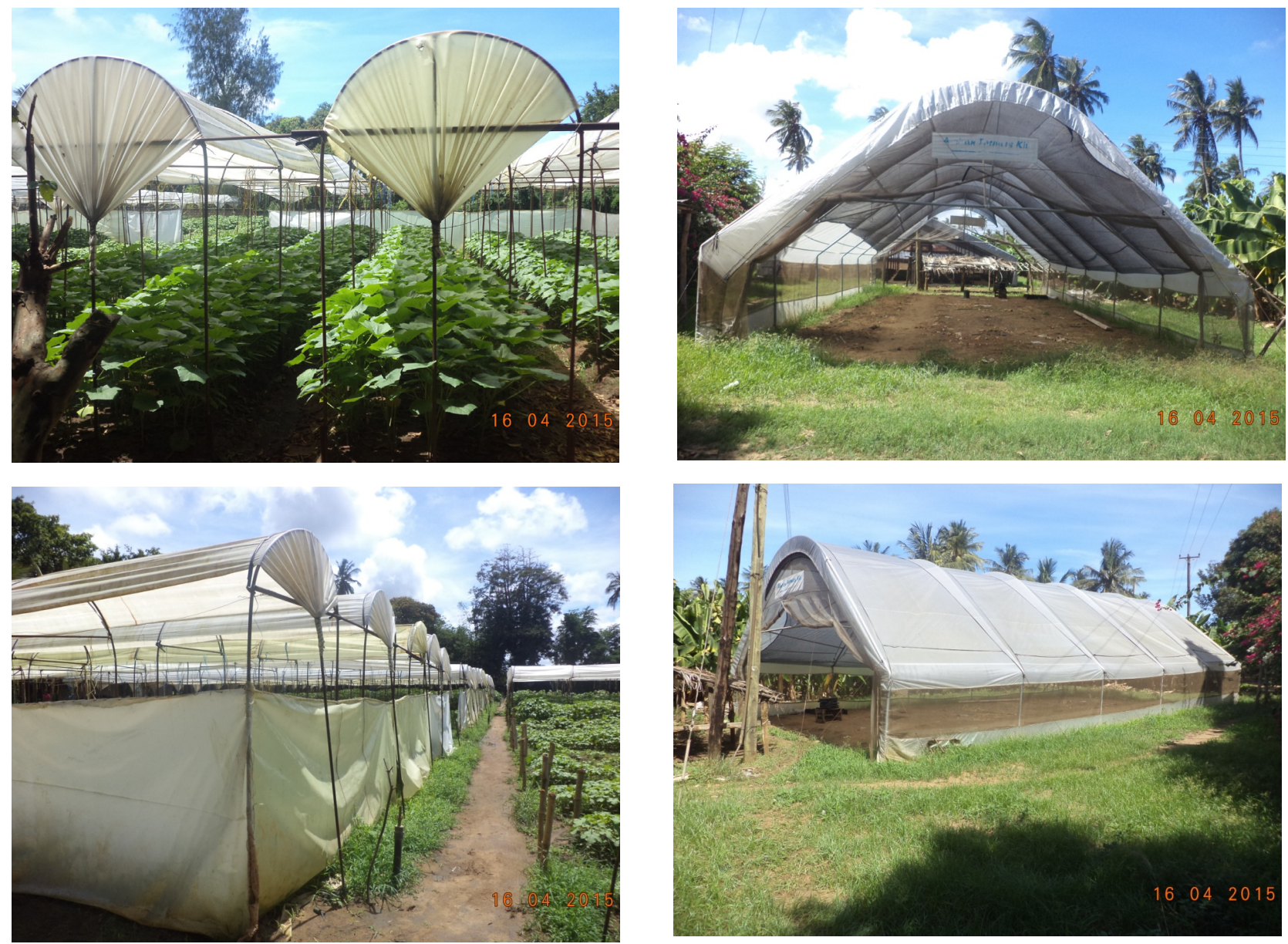

Figure 2. Farmer-made-greenhouses at Kikambala-KIK-1

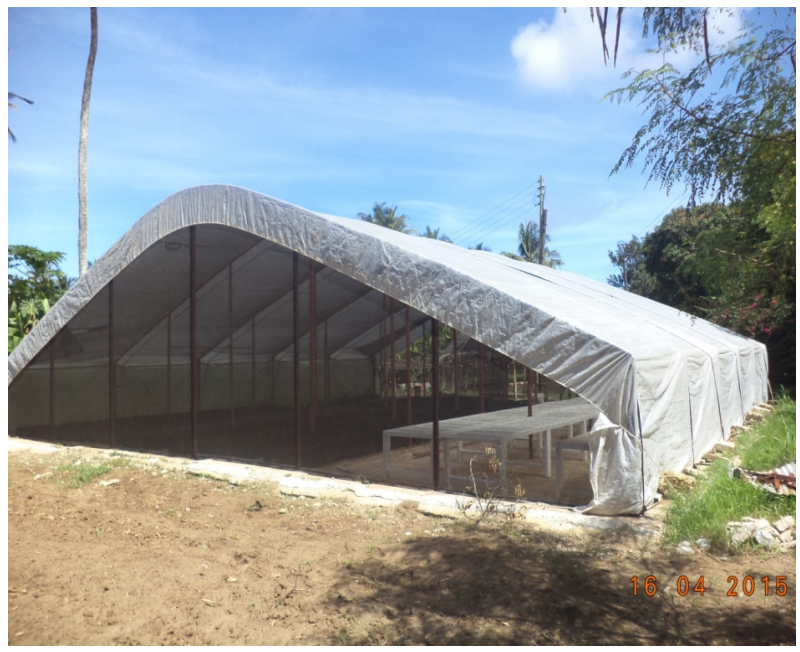

Figure 4. Modified Amiran model with under-ceiling black shade net

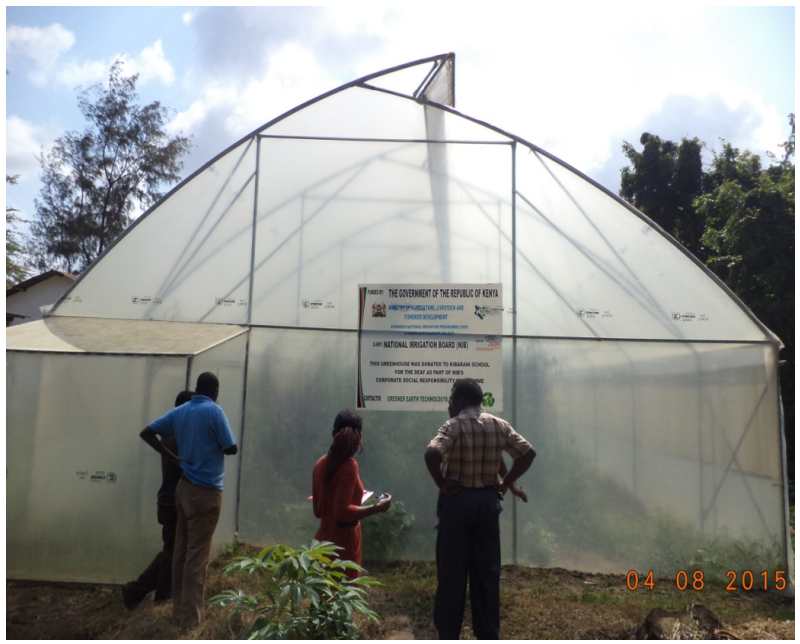

Figure 3: Amiran-2 at Kikambala 


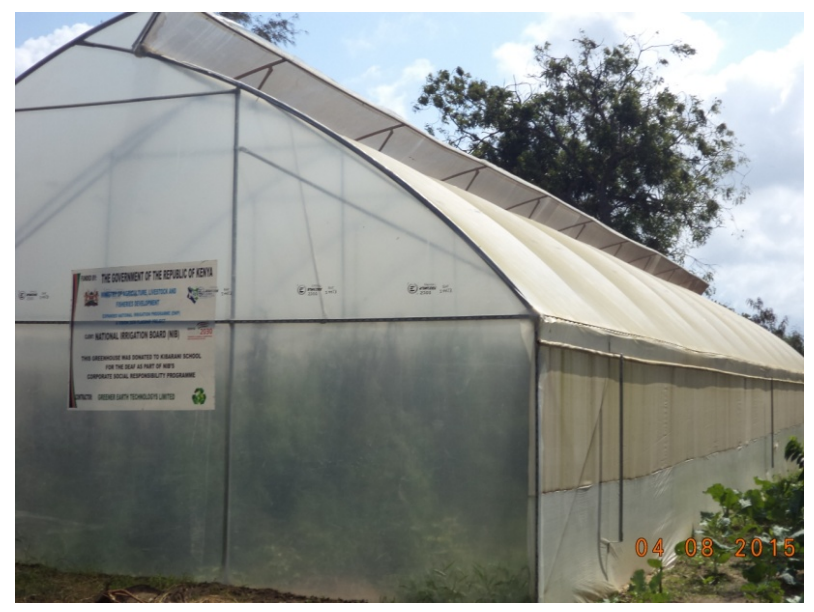

Figure 5. Greener Earth Technologies design at Kibarani -Kilifi
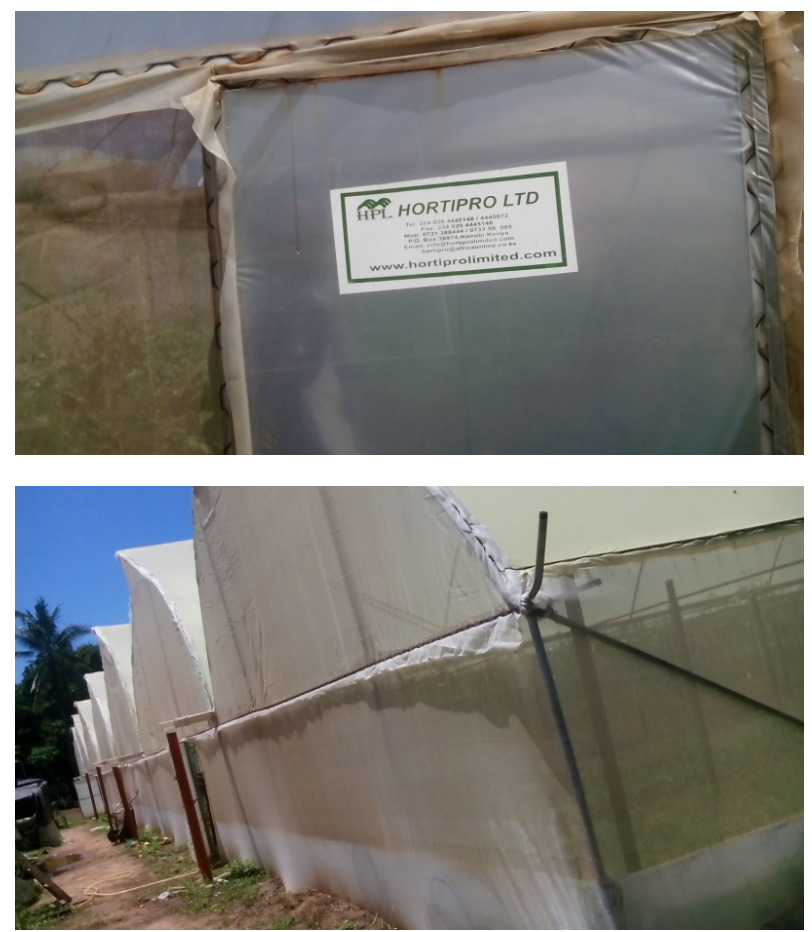

Figure 6. Hortipro Design at Takaungu

\section{Greenhouse Distribution in the Project Area}

Kilifi County is leading in the adoption of greenhouse technology. More individuals had adopted the production technology compared to Kwale and Mombasa Counties respectively.

\section{Area under greenhouse production in the project Counties}

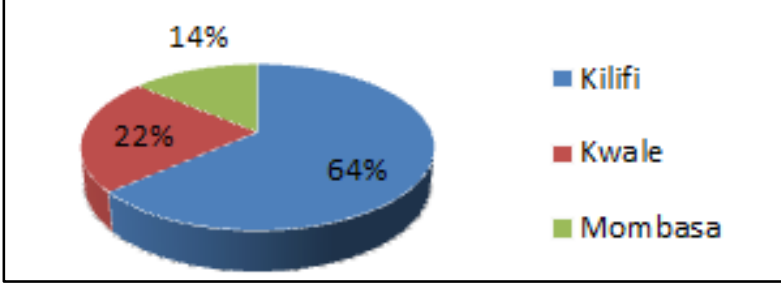

There.was marked variation. on the spartial-distribution. of greenhouses in the three. counties. Most Greenhouses: were found along the $\mathrm{CL} 2$. and CI3. In.Kilifi.county. therewas wigh. concentration of . greenhouses around.Kilifi. north and Kilifi-Southsubcountiesalong Mtwapa, Kikambala, Takaunguand. Kilifi-town; while-in-Kwale. 90\%.of the greenhouses. were found in MatugasubCountyespeciallywaa and. Golini-locations. In: Mombasathey were found. randomlyin:

Bamburi, Kongoweaand. Likoni-locations.

Figure 7. Relative Area Covered by Greenhouse Compared to Agricultural Land in the Project Area 

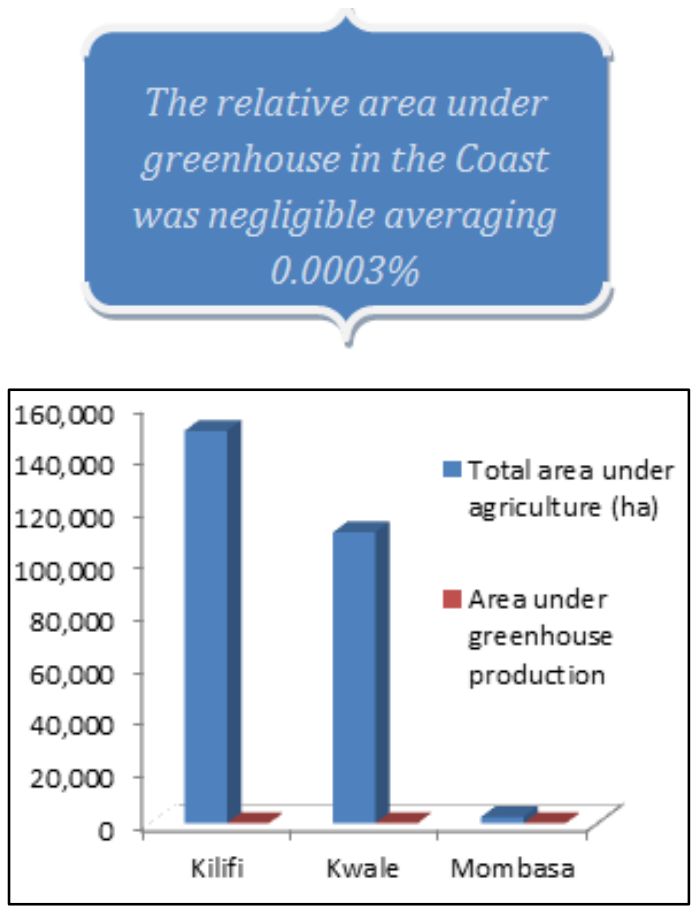

Figure 8.

Table 1. Greenhouse operation status in the coastal Counties of Kenya

$\begin{array}{cc}\text { County } & \begin{array}{c}\text { Percentage of operational } \\ \text { greenhouses }\end{array} \\ \text { Mombasa } & 39 \\ \text { Kilifi } & 44 \\ \text { Kwale } & 17\end{array}$

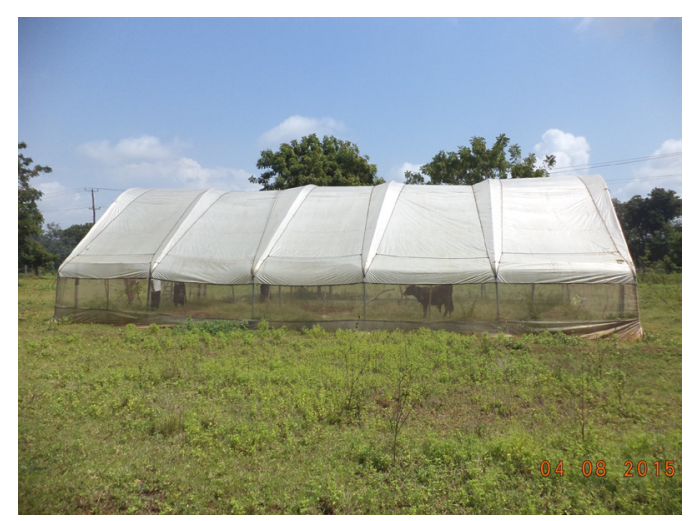

One of the abandoned

greenhouses turned to

grazing field for cows in

Mombasa County.

Figure 9. Amiran model greenhouse

General Findings about Greenhouse Farming in the

\section{Coastal Humid Region of Kenya}

All farmers interviewed concurred that greenhouse tomatoes offered the best quality with large red tomatoes being the excitement of farmers. Forty out of the 55 farmers rated the greenhouse technology between excellent and good if the current challenges facing them were addressed. Most of the abandoned greenhouses were owned by institutions or groups. The main crop being grown is tomato. Some farmers however were seen growing field tomato varieties in the greenhouse such as Kilele which is a medium determinate and elongated hybrid for bush and staked cultures, suitable for dry and humid areas with early maturity and M82 which is a mutant variety. These varieties were not doing very well. Other crops found in the greenhouses included sweet melon, okra, amaranth, spinach, kales, beet root and cow peas; mostly as rotational crop.

\section{Challenges Facing Greenhouse Production in the Hot Humid Coastal Kenya}

There was a big micro-climate management challenge especially with Amiran-1 Model. This was found to retain high temperatures in the greenhouse as high as $50^{\circ} \mathrm{C}$. All such models had failed. This caused loss of production resulting from thermo-stress. Another important challenge are diseases. The most common disease observed was late blight. However Fusarium wilt was also present in some greenhouses. Finally, irregular watering and nutrition by farmers resulted in disorders such as blossom end rot.

Coastal area has a problem of water quality. Most farmers use saline water from wells to irrigate crops. This has contributed to reduced yields causing farmers to abandon farming over years. In some cases especially in institutions, lack of and inadequacy of quality water was a problem. Also, Farmers reported lack of extension support from the government. Some were learning from the internet, others through agricultural exhibitions while others learnt from neighbours. Those that could not reach any help did trial and error methods to solve problems affecting them. Hamisi Mwachidudu is a devastated farmer who sunk his retirement money into greenhouse farming and has since not reaped anything. He has suffered blights, bacterial wilts and thrips. Amiran who supplied the kit deserted him and offered no technical support. Other highlighted challenges include; leadership wrangles, political interference on management of the several greenhouses donated by politicians that posed danger to disintegration of groups and hence collapse of greenhouses. Finally, some farmers especially the large scale farmers reported underpricing of greenhouse tomatoes in the local market. Hence a shift to other crops. Small scale farmers do not find ready markets.

Pests: Tuta absoluta was reported in one of the large scale greenhouse farms in Kilifi County. Other pests included American bollworms and nematodes. Nematodes infestations are a calamity in greenhouse production in the Coast. 

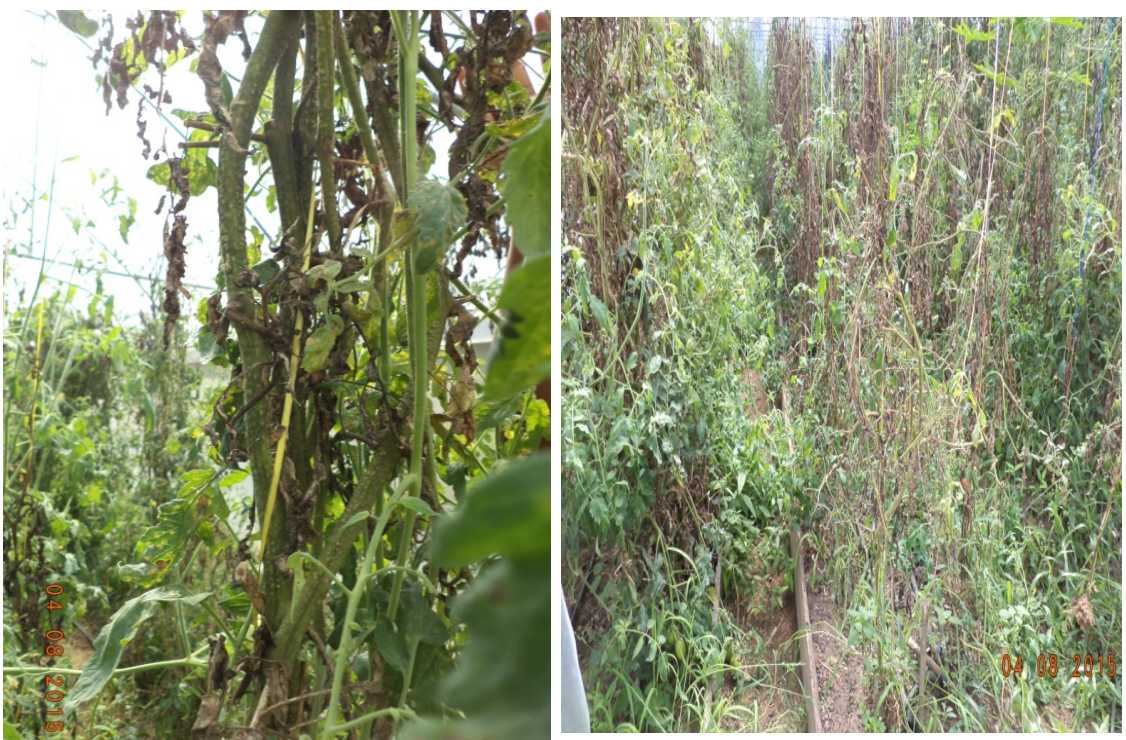

Figure 10. Blight infested tomato crop at Kibarani
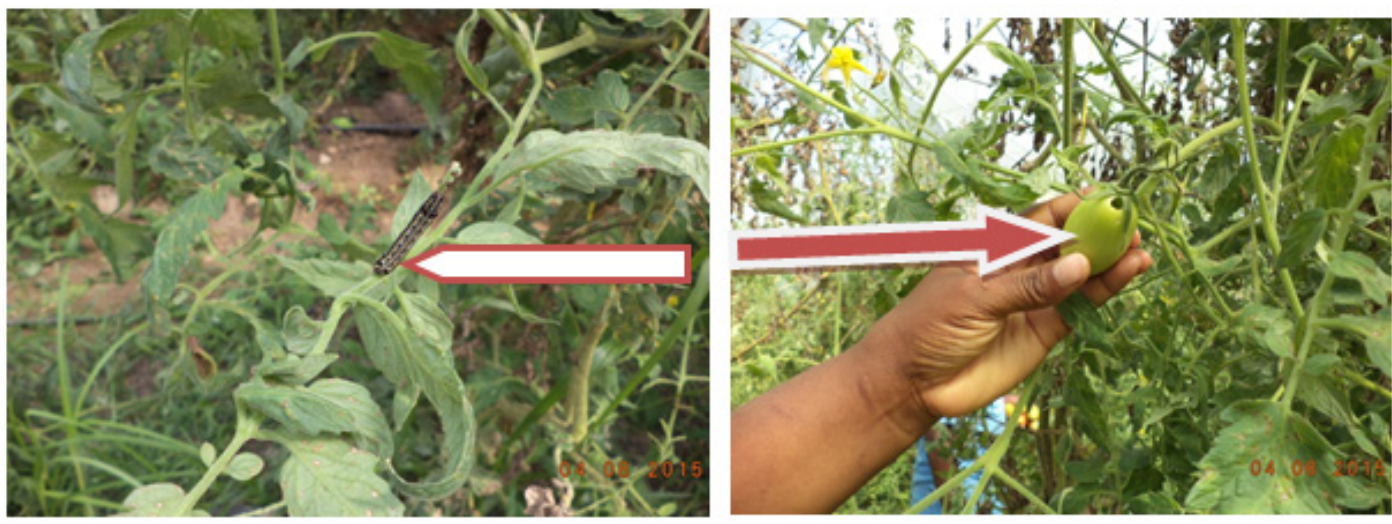

Figure 11. American bollworm infestation
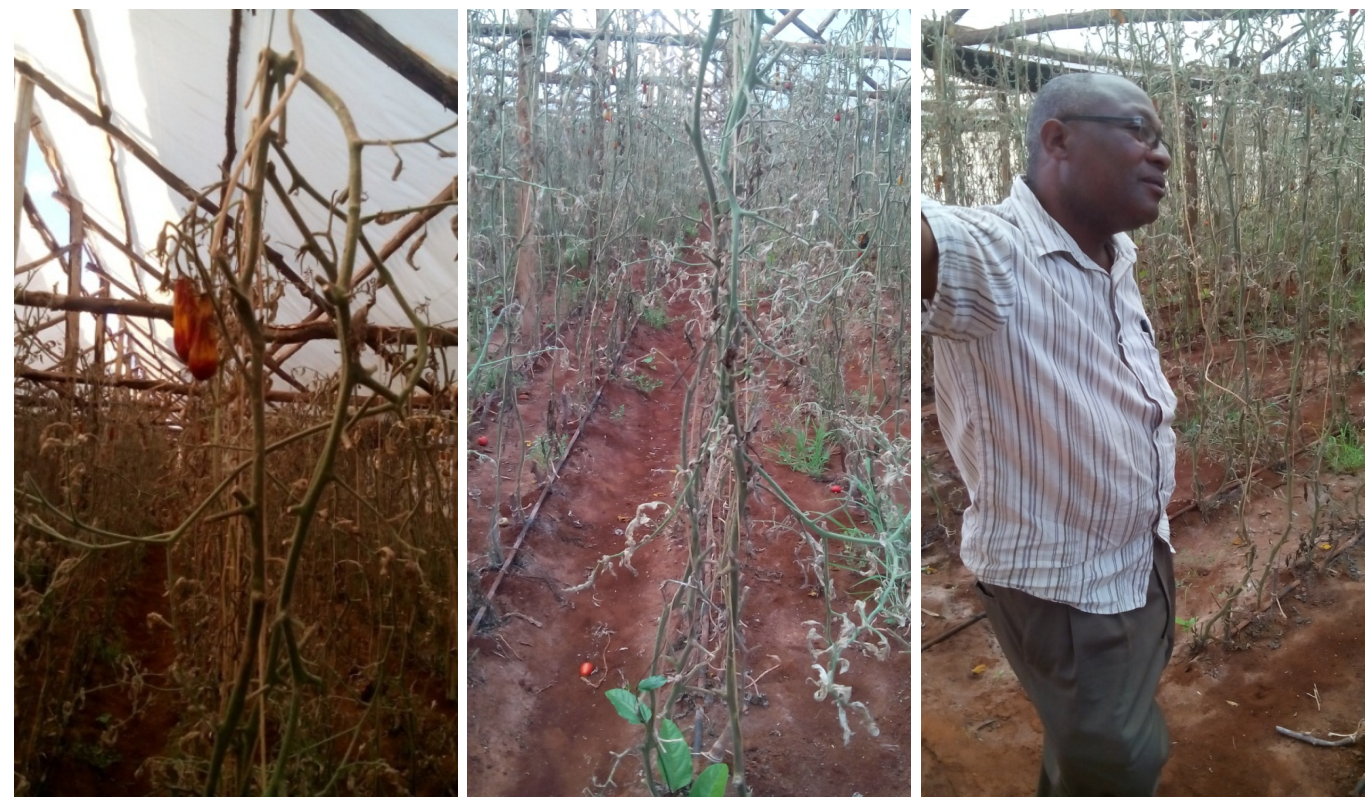

Source: Chawia.farm, (2015)

Figure 12. Tuta absoluta damage Meyrick [8]. 


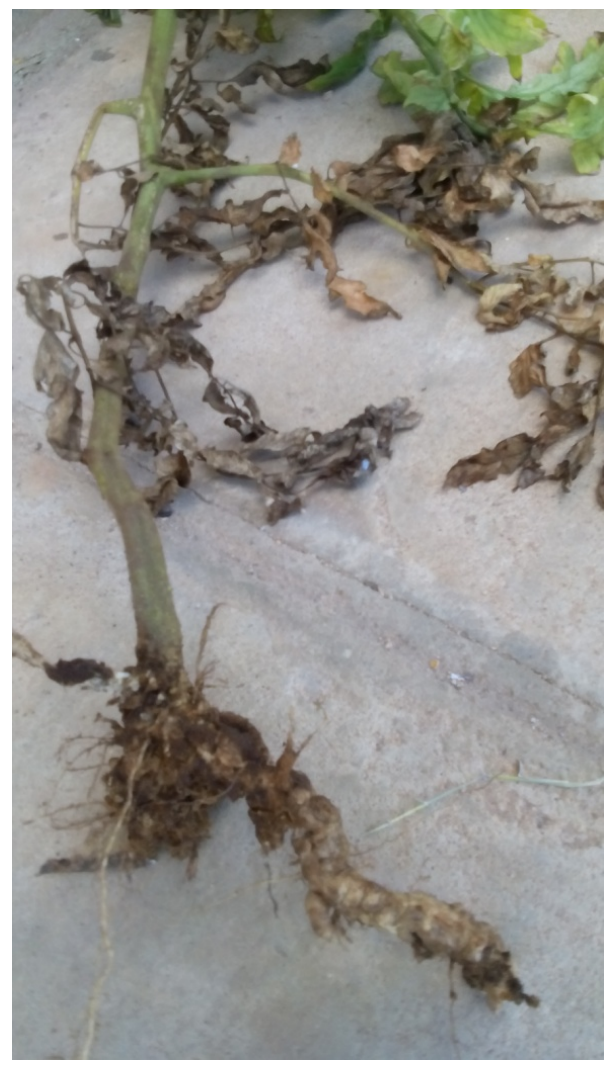

Figure 13. Nematode infestation on tomato

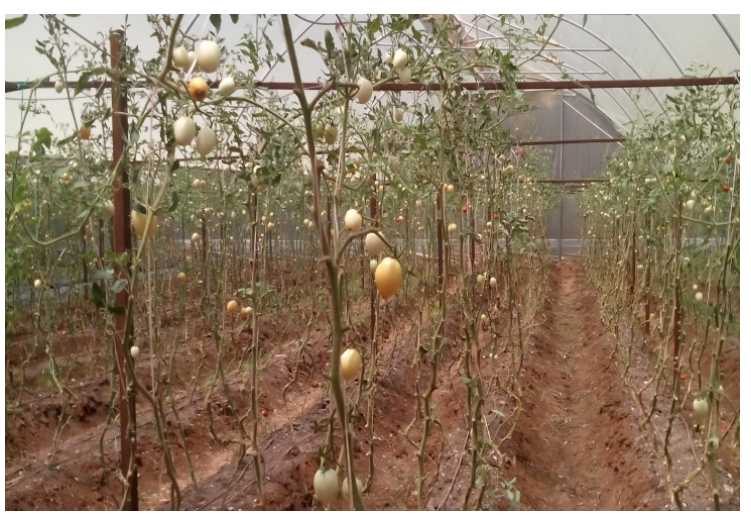

Figure 14. Wilted tomato plants due to nematode infestation

\section{Discussion}

Model of greenhouses by Amiran Ltd have dominated the coastal humid region in Kenya because apart from being the pioneers of the technology promotion in the Country, they also have a structured distribution, marketing and support system on the ground where they can easily be contacted once problems are experienced at the farmer level. Furthermore they have continuous on-farm evaluation and research to improve on the performance of their designs in the market. To date there are four designs in the market. However, the designs observed in the field were operating at very low performance. This poor performance can be attributed to the climatic condition which is hot and humid and requires very effective ventilation. This calls for necessary modifications in the design to allow cooler and moderately humid micro-climate to boost performance of crops.

The low adoption rates of the greenhouse technology in the study were partly as a result of the challenges of micro-climate management, water quality and quantity. However, political interference contributed to failure of most group owned installations since most politicians used them for political mileage and were abandoned immediately the politicians who introduced them failed to be re-elected. This scenario indicates that greenhouse farming requires proper and real time management for success. It is best as an individual investment and group installations should only be used for demonstrations.

Majority of greenhouses were found in conventionally favourable agricultural areas. This was mainly because of the fear of facing failure in drought prone areas. The County governments should develop irrigation infrastructure in the remote areas of coastal lowland zone 4 (CL4) to popularize the technology where rainfed systems have failed.

The study notes that greenhouses were relatively few in Mombasa County where all advantages of production and marketing are available. There is need to sensitize the urban community to embrace greenhouses as an urban agricultural technology to boost incomes for the unemployed. Farmers in the project area are of the opinion that with increased technical support and extension, greenhouses can be a great investment in the region. The survey indicated that the rate of greenhouse failure was high where there is bureaucracy in management and approvals while groups mainly collapsed due to group dynamics.

\section{Conclusions}

The greenhouse potential in the coastal humid region of Kenya is unexploited and stands a chance of revolutionizing agricultural productivity and farm incomes in the region. Expansion of the technology should not be left to the private sector but government should be fully involved until sustainable adoption levels of the technology have been reached. Appropriate greenhouse designs, Extensive greenhouse extension services and installation of support infrastructure such as access to quality irrigation water will promote greater adoption and performance of the greenhouse technology in the hot humid climatic regions in the coastal Kenya

\section{Acknowledgements}

The authors thank NACOSTI, Barclays Bank, Pwani University and coastal region Counties for provision of resources. 


\section{Conflict of Interest}

The authors declare no conflicting interests

\section{REFERENCES}

[1] Aberkani K, Xiuming H., Damien H., Martine D., Stephen V. and André G. (2010). Effects of Shading Using a Retractable Liquid Foam Technology on Greenhouse and Plant Microclimates. HortTechnology VOL. 20:283-291

[2] Snyder R. (2009) Greenhouse Tomato Handbook www.http://msucares.com/pubs/publications/p1828

[3] Jolliet O., Bailey B., Hand D.J. and Cockshull, K. (1993) Tomato Yield In Greenhouses Related To Humidity and Transpiration. Acta Hort. (ISHS) 328:115-124

[4] Körner O., and. Challaw H. (2003) Process-based humidity control regime for greenhouse e crops. Wageningen University.

[5] Hortinews (2013) Greenhouse tomato farming. www.hortinews.co.ke/article.php?id=258Accessed 2nd June 2014.

[6] Arbel A, Yekutieli O, Barak M. (2003). Performance of a Fog System for Cooling Greenhouses. Journal of Agricultural Engineering Research [Internet]. Elsevier BV; 1999 Feb;72(2):129â36. Available from: http://dx.doi.org/10.1006/jaer.1998.0351

[7] Sanzua L.J., R.Wanjogu , J. Njoka and H.M. Saha.(2014) Evaluation of performance of small scale greenhouses and drip irrigation technologies in western Kenya. NIB-Ahero Irrigation Research Station.

Zekeya N., M. Chacha, P. A. Ndakidemi., C. Materu, M. Chidege and E. R. Mbega (2017). Tomato Leaf Miner (Tuta absoluta Meyrick, 1917): A Threat to Tomato Production in Africa. Journal of Agriculture and Ecology Research International. Vol 10 (1): 1-10 